\title{
THE REFLECTION OF PEDAGOGUE'S IDENTITY IN THE LIFE ACTIVITIES: THEORETICAL RESEARCH MODEL
}

\author{
Arturs Medveckis \\ Liepaja University Sociological Research Center, Latvia
}

\begin{abstract}
The innovative research model presented in this article includes the micro, mezzo, and macro context of the identity by expressing its multiple dimensions of the pedagogue's personality in personal, cultural and historical and social aspect. The dispositional traits of personality i.e. emotions, talent, behaviour and opinion, along with the adaptation characteristics i.e. interests, motivation, values, attitudes and character are analysed in the micro context. The meaning of the respective social environment is drawn in the mezzo context where the pedagogue's, family, student's and religious identity develop. The further crystallisation of the identity happens in the macro context that influences the development of professional, national, local, political and cultural identity.
\end{abstract}

Keywords: biographical approach, personality, the structure of the personality, identity of the personality, identity research model.

\section{Introduction}

The theoretical research model of pedagogue's identity is developed as a part of biographical research conducted by the author (Medveckis, 2004, 2006, 2007, 2009, 2012, 2013, 2013a, 2014). As a result the Research Model of Pedagogues Personality has been developed and presented on IJAS conference in Prague \& Rome (2013), Freiburg (2014) and was first published in the International Journal of Multidisciplinary Thought (Medveckis, 2015). The concept of the research model of pedagogue's personality is based on the integrity of the personality i.e. holistic approach. On the ground of the traditions of the qualitative research analysis (Thompson, 2000; Abrams, 2010) the theoretical concept of the personality includes the understanding about dispositional traits of personality: behaviour, talent, the individual differences of thoughts and emotions, followed by the adaptation characteristics: motives, aims, interests, values, identity and the integrative life story (McAdams \& Pals, 2007).

The holistic view of the personality and the analysis of its components according to Karpova (Karpova, 2005: 9) draws a conclusion that personality is a monumental creation and will be an issue for scientist for a long time because, firstly, it includes the most important aspects of an individual's being, activity and characteristics and, secondly, it takes decisions influenced by the heredity, 
environment, situation and experience (special historical circumstances). Thus, the personality is not completely free but is capable of self-regulation and selfdetermination on the ground of self-perceived and self-tested universal values.

Liegeniece's researches (Lieǵeniece, 1992, 1996, 1999, 2002, 2013 etc.) on the holistic analysis of various personality aspects focus on the early stage of the development of the personality. As concluded by Samusevica (Samuseviča, 2013: 361), the development of the holistic approach has given Liegeniece the opportunity to look in particular into the issues of self-regulation and development conditions, problems and opportunities of the different individuals in context of social and cultural environment.

The understanding of life activity in this research is based on the conclusions of Ausma Spona (along with further studies by Elita Volane and Ainars Spons) that draw a system of manners and attitudes for individual's activity and satisfaction of needs developed within the cognitive process of oneself, society and nature (Špona, 2006, Volāne \& Špons, 2010). A significant research is also conducted by Kruze resulted in the publications of Latvian pedagogical researchers in "Laikmets and personība" (Karpova, Kestere, Špona, Kalıke, Vugule, Vedišceva, Ol̦ehnoviča, Bernāts, Sīle, Samuseviča, Medveckis, Zigmunde, Meikšāne, etc.)

Thus the author of this research started a more in depths examination of pedagogue's identity that lead to the development of a new research model of pedagogue's identity and its influential factors.

\section{The Components of the Holistic Structure of Pedagogue's Personality}

The theoretical aspect of the research model of personality is based on the conclusions of the USA psychologist Salvatore Maddi about personality. $\mathrm{He}$ indicates the core and the periphery of the personality. According to Maddi, each personality has the core characteristics that do not change during the lifetime and significantly influence the behaviour, activity and its results (the inherited potential, abilities, aims, principles etc.). At the same time the periphery also has sustainable behavioural characteristics e.g. behavioural styles and models, motivation, features, schemes etc.) (Maddi, 1996).

Similar core and periphery concept is presented by Illeris in his work Transformative Learning and Identity (Illeris, 2014) and by Strika who according to different psychological theories (McAdams, \& Pals, 2007; McCrae, \& Costa, 1997) structures personality in three groups: dispositional traits, characteristic adaptations and integrative life stories. Dispositional traits of personality are defined as broad dimensions of psychological individuality that describe assumedly internal, stable, and global individual differences in behaviour, thought, and feeling. Traits account for consistency in individual 
functioning across different situations and over time. In general dispositional traits are measured using the methods of personality self-evaluation. Second group involves wide range of such personality constructs as motives, goals, and projects, values and beliefs, cognitive schemas and styles, Ego and psychosocial stages, coping strategies, defence mechanisms. They all are called characteristic adaptations. These characterizers describe what a person wants from the life and what he does in order to achieve it and how the person avoids from what he doesn't want. Characteristic adaptations are usually contextualized in time, place, situation or social role. Third group comprises individual's integrative life story that is internalized and evolving narratives of the self that people construct to integrate the past, present, and future and provide life with some sense of unity, purpose, and meaning (Strika, 2009).

The socialisation processes influence personality development processes in early childhood and self-regulation as the recourse of inner evolution (Lieǵeniece, 1999, 1997). The cognitive sphere, emotionality, willingness, necessity and interests are essential within the self-regulation process (Lieǵeniece, 2013). The theoretical context of socialisation process is based on the theory of interactionism represented by Cooley, Mead (Balantine \& Roberts 2009). According to them the socialisation process is the result of social interaction involving various agents i.e. family, school, public organisations etc. The transformation of the individual to a member of society is based on the subject-oriented perspective, intuition-oriented perspective and culture-oriented perspective (Gudjons, 1998). The pedagogue's role within the socialisation process is rooted in Parson's understanding of socialisation process and family values (Vikmane, 2009).

The author's conclusion meet the idea of other researchers that within the micro context of the personality essential are social factors, within the mezzo context - structural conditions and within the macro context - state politics (McKeracher 2004; Bruning, 2002; Cross 1981).

\section{The Understanding of Identity: Social Aspect}

Scientific literature deals with various perspectives and contexts of the identity. The identity refers to the idea of being and belonging and the ways individuals make sense of themselves (Bisley, 2007). According to Stepčenko, the individual identity in context of collective, national and regional identity is selfness discovered in self-identification, which consists of interweaving and overlapping of various identities (Stepčenko, 2014: 63). Zobena, Grīviña and Nikišina draw conclusions that the concept of identity has cardinally changed also historically - from a philosophical concept about an individual's characteristic and personality traits to identity constructions, which can be 
changed by the individual. Furthermore, the circle of agents referring to the concept has also widened. We can talk about the identity not only in the context of an individual, but also of a place, object and time (Zobena, Grīvinšs \& N,ikišina 2014: 7-8). Bela-Krūmina refers to the identity as a story created by people about their peers and living space. The regional identity defines the individuals relations with the respective region, social system and history i.e. landscape, inhabitants, culture, traditions etc. (Bela-Krūmiņa, 2005: 25). Berger and Luckmann have a similar interpretation of the identity outlining it as an element of subjective reality, which remains in dialectical interaction with society and is influenced by social processes. Once crystalized it is sustained and can change due to the social relationships. The social process related to the development and maintenance of identity is determined by the social structure and vice versa (Berger \& Luckmann, 1966).

The representative of the symbolic interactionism Cooley in his "I" theory outlines that the self-awareness of an individual is formed by the individual's perception of what others think of him/her, how others evaluate him/her and how this interaction results in self-evaluation (Ballantine, Roberts, 2009). Mead draws similar conclusions about the functioning of the individual and the social life, which can result in readjustment or conflict and crystalize the concept of selfness internally differentiated as "Me" and "I". "Me" is formed by the opinion of others, which have become a part of personality with its social ground. The structure of "I" characterises that part of individuality elements, which are result of personality actions (Baldwin, 2009; Charon, 2004). According to Mead the social reality is created within individuals' interaction by means of symbols and their manipulations with a special meaning of language and gesticulation. Symbols not only transfer general information to various individuals but also they carry significant individual values, as they are the main functioning tool (Volkovs, 2011). The symbolic meaning of language in connection to identity is mentioned also by Druviete who outlined that the base element of some ethnos can be different - religion, culture, common geographical space, even national cuisine, however, in most cases the base of the identity is language (Druviete, 2010).

Danish professor Knud Illeris conducts that "like other mental conditions the identity is created, developed and changed through learning - which all take place in interplay with innate dispositions that are integrated in the learning processes and thereby can influence the learning as well as the identity. So even though various kinds of characteristics of the identity can be said to be inherited, the transfer takes place as an integrated element of the learning process. Therefore the identity also includes the three dimensions - content, incentive and interaction (Illeris, 2014: 69). According to the Danish professor the identity in the learning process is connected to the individual and the surrounding and 
"always involves the three same dimensions, i.e. the content or the cognitive, the incentive or the emotional and the interaction or the social (Illeris, 2014: 70) and outlines the main identity, which unites the identity elements, as the central part of his identity concept. Giddens has proposed it as self-image that reflects the individual life (Gidenss, 1999), Erkinsen calls it biographical identity (Erkinsen 2010), Erikson names it the ego-identity (Erikson, 1998). A specific issue is the biographic identity (Alheit, 1992, 1999) and Pierre Bourdieu's habitus concept, which is understood as unconscious embedding in the individual, while the core identity is mainly conscious (Illeris, 2014: 72). Thus, habitus may be understood as a term for the unconscious elements of the individual mental core. However, habitus also includes elements belonging to the personality layer, which includes aspects of how the individual wants to be and appear to others the surrounding world (Illeris, 2014: 73). Thus the personality layer typically includes conditions like values, attitudes, convictions, meanings, understandings, forms of behaviours, habits of communication, patters of collaboration, empathy, social distance and caution (Illeris, 2014: 74). The personality layer has certain similarities with dispositional traits of personality outlined by Strika that unite emotions, character, talent, while the characteristic adaptations include values, attitudes, interests and motivation (Strika, 2009).

There are various interpretations of emotions both as physiological, neurological, behavioural and verbal reaction on inner or outer irritations important for a humans life (Fox, 2008), and from the antidote perspective as positive, negative (Plutchik, 2002). In addition, there are also base emotions whose amount can be various. The most common are Ekman's classification of base emotions: anger, disgust, fear, joy, sadness and surprise (Ekman, 1992) and Izard's inherited base emotions like interest, joy, surprise, suffer, disgust, anger, shame, fear and contempt (Izard, 2009). When the base emotions transform, the secondary emotions appear, which often are considered as feelings: love, devotion, reverence, disappointment, regression, aggression and optimism (Mihailova, 2015). Feelings are interpreted as human's emotional process that shows relatively independent subjective attitude towards important real and abstract objects/ subjects for the individual. They develop due to socialisation and usually refer to significant values of the individual (Mihailova, 2015: 175).

The character is a unity of person's individual characteristics and peculiarities, which accrue in actions, attitudes and behaviour. In Latvian scientific literature character refers to educational issues of personality that form the basis for Latvian pedagogical psychology (Dāle, 1962; Students, 1928, 1930, 1935; Celms, 1933) and continued within the holistic researches by D. Liegeniece, I. Salite and I. Mikelsone.

Motivation consists of inner and outer motives that encourage definite individual's behaviour and the behaviour is connected to a specific aim to meet 
specific needs. The needs are biologically and socially defined and are researched by various theories of motivation. Firstly, there is the theory of needs visualised by the pyramid of needs by Maslow (Maslow, 1954) and his followers Alderfer who shortened Maslow's pyramid to the three components: existential needs, a need for relationships and a need for development, Herzberg who developed two factors theory about the satisfaction of need and the prevention of dissatisfaction. Another follower is McClelland and his achievement motivation theory. He bases his opinion on the assumption that human beings are motivated by the need of achievement, power and relationships. Vroom's theory of goal setting and task motivation considers the individual's subjective perception evaluation of the situation and the clearness of the aim.

The motivation of the pedagogue's self-realisation is defined by the deepness and wideness of the personality influenced by the interactive person's character traits, skills and attitudes (Parson, 2011). The values are interpreted in moral, aesthetic and universal dimensions, considering that the values are fundamental believes that define and motivate attitudes and actions (Definitions of Values. In Ethics, Compliance, Initiative).

The attitude can be defined as a long-term emotional expression of perception and cognitive processes, often reduced to "like - don't like" evaluation. The social pedagogical aspect of the definition has both widened and narrowed concluding that the attitude itself is difficult to evaluate but it can be deducted from person's self-evaluation and behaviour (Schwarz \& Bohner, 2001).

The interests include emotional and cognitive components that connect the individual with a specific activity in a specific field (Schiefele, 1992, 1996). The emotional and cognitive expressions define the willingness to involve, which can be influenced by the emotional experience.

According to the core identity is developed and changed by learning during the life course. But at the same time it is also a task of the core identity to secure continuity and therefore changes usually only happen gradually and often almost imperceptibly if the individual is not exposed to sudden and profound changes of life conditions defined by Erkisen as a transition from one age period to the next (Eriksen, 1998) or by Gidenss as a different spacetime (Gidenss, 1998).

Illeris illustrates the identity as core that must include something more, something that lies outside and around the core and reaches out towards the various connections to the surrounding world. Thus, the core identity can be seen as innermost and most basic of the three concerning layers that is surrounded by the attached personality layer, which is related to Erikson's concept of ego-identity. The personality layer is more flexible and more susceptible to change when the individual receives important new impressions 
or experiences new conditions (Illeris, 2014: 74). The preference layer includes all the many different conditions the individual meets in his/her daily life i.e. his/her daily identity and it is about what and how the individual more or less automatically prefers, how one thinks and acts in all of the many situations in which no special considerations or efforts are involved. However, part-identities are related to one or two of the main areas that can be broadly termed our attitudes and our practice, which at the same time indicates that these partidentities may be more or less different kind in different cultures with different traditions and norms and for different groups of people with different kinds of practice (Illeris, 2014: 74-75).

Part-identities in relation to practice can typically be grouped in three main areas that can be termed the work identity, the family identity and everyday life or interest identity. Regarding attitudes the part-identities can be grouped in three main categories that can be termed the national-cultural identity, the religious identity and the political identity (Illeris, 2014: 75). According to Illeris, each of these part-identities is closely connected to core identity and in the same time they have their own core. It is important that all these various paridentities are parts of an individual pattern and interaction in which some parts may be closely related, while others are far from each other and there may be elements that more or less in contrast (Illeris, 2014-75).

Hooks outlines two ways of forming definitions to explain culture. The first includes the emergence and the transfer of identities, meanings, knowledge, conviction, values, memories and attitudes of society. The second is more focused on a definite community's lifestyle, including traditions, customs, style, religion, behaviour and rituals (Hook, 2007).

The cultural environment is termed as the individual's activities in the cultural area where he/she exists as a social subject and interacts with subject influencing factors. The structure of the culture consists of material and nonmaterial culture (Macionis \& Plummer, 1998).

The social identity is the result of an agreement between the individual and the social group or society (Jenkins, 2008). Sociologist Volkov draws further conclusions on the ground of Jenkin's approach that the scientific interest about social identities is connected to the modern society's deep transformation due to postmodernism. HE defines social identity as the knowledge about the personality's individual belonging to a specific social group and at the same time emotional and evaluative attitude towards this belonging.

Volkovs also concludes that in the modern Latvian society there is a topical need for the belonging to a community and area and a desire to protect one's linguistic identity and the social identity providers are not only social groups but also definite personalities, and Latvian sociologists among all social identities, are mostly interested in national and ethical identity. Thus, Volkovs's 
conclusions link to Iller's ideas about the transformation of identity and outlines that the social identity of the personality continuously evolves, as the socialisation process has to be considered as the atrobut of human' $\mathrm{s}$ life (Volkovs, 2015). According to Koroleva, Rungule, Snikere and Aleksandrovs, the formation of the identity is one of the most important tasks of juvenescence (Koroḷeva, Rungule, Sniķere \& Aleksandrovs, 2009: 145).

Gudjons also emphesizes that, as well as the childhood has to be overlived, also the thinking about the future is essential (Gudjon, 1998: 152) and Lenzen outlines the role differences, individual ideals, values and norms and draws attention to biographical consciousness which in the context of historical and social situation colours the "I" identity.

\section{Discourse of the Pedagogue's Professional Identity}

The "I" identity is analysed in the Lace's research about the influential factors of Latvian pedagogues' career. According to Lace, career includes the professional individual evolvement during the whole lifetime. It is connected to the human's development in the main life activities (work, family, relaxation) and human's social activity. Furthermore, by developing the career the individual improves one's professional "I" concept and answers questions about personality skills, competences, main life motives, aims etc. (Lāce, 2011). The mentioned assumptions are linked to Callalan's idea that nowadays the key to a successful career is a clear development of identity, the definition of the career aims and finally the selection of career strategy (Callalan, 2003).

When characterizing pedagogue's identity Mikelsone, Odina and Grigel emphasize the importance of holistic research based on the interplay of economic, social and political problems. Thus, an interdisciplinary approach to teachers' education is required with a focus on teachers' professional identity and lifelong learning. The analysis of the professional identity is based on the individual's understanding of the professional and individual evolvement and a universal and dynamic development in the main life areas (work family, relaxation). Thus, when analysing the concept of the professional identity it should be closely linked between concepts of "professional career" and "development of personality", along with "career" and "self-understanding" (Miķelsone, Odina \& Grigule, 2014).

The development of professional identity is a process that includes the knowledge about teaching, inspiring, about relationships and the teaching subject which according to Sugrue roots in the pedagogue's personality and is influenced by the closes family members, other relatives, experience, interesting teaching episodes, political context, teaching traditions and cultural archetypes (Sugrue, 1997). 
Referring the pedagogue's identity there are several common features e.g. university pedagogues teach and values as a professional group with common professional perspectives about teaching learning (Nixon, 1996). According to Pechter and Head the common primary teachers' identity component is the desire to take care of the child. By teaching low status subjects the teacher tries to find the professional identity in the teaching process in general. Furthermore, for the experienced teachers significant is such aspects as the interaction with students, the commitment to serve the students which should be more important as personal dissatisfaction with working environment (Pechter \& Head, 1996).

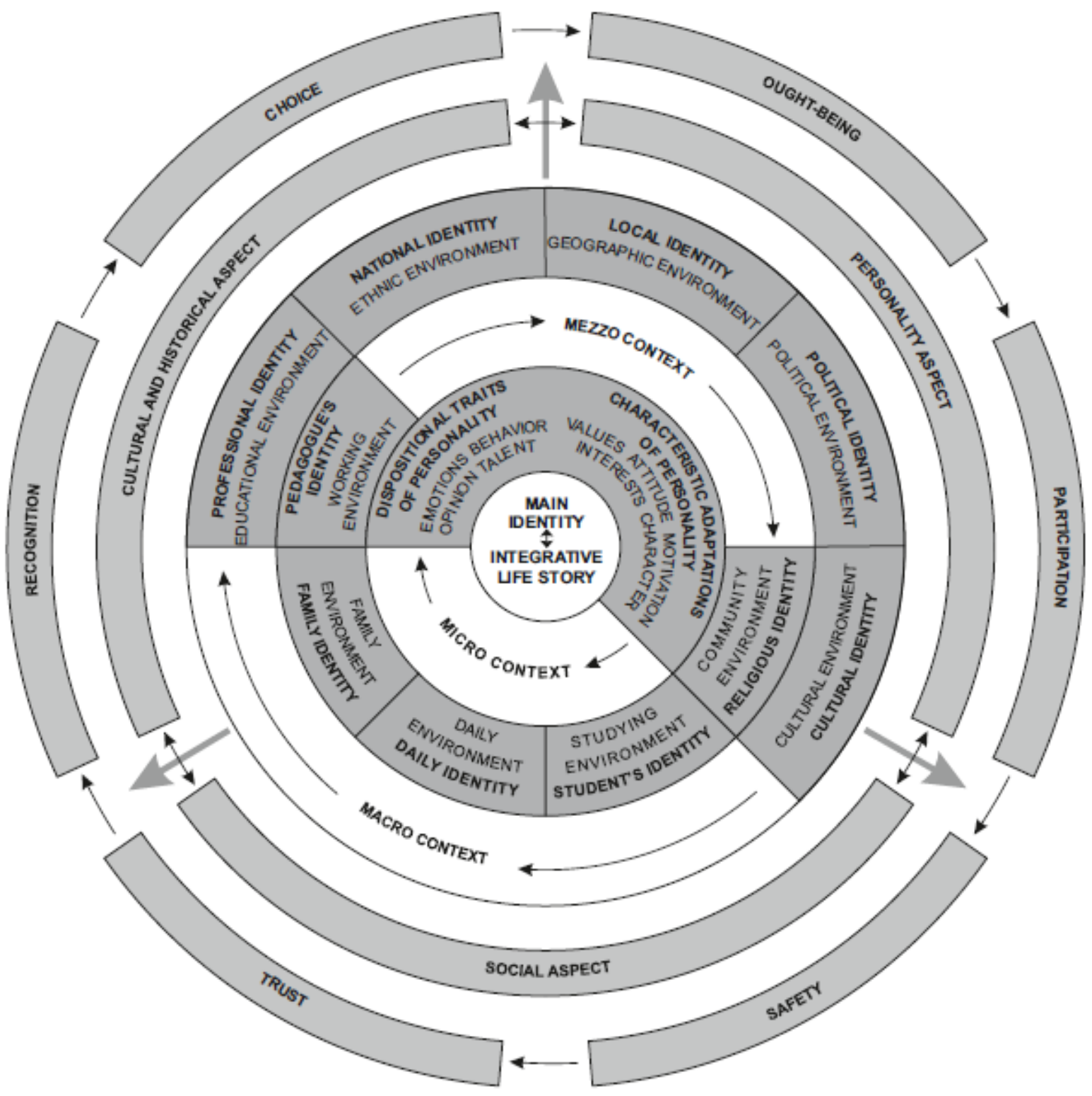

Figure 1 Research Model of Pedagogue's Identity and its Influential Factors 
Moore and Hofman's research outline that the school's aspiration for quality refers to a highly developed professional identity (Moore \& Hofman, 1988).

The process of becoming a professional is an interaction between the values others find significant in a pedagogue and the pedagogue's own values. It includes the process of growing defined by the learning from one's own experience and sharing this experience (Phelan, 2000).

The biographical research, the analysis of the pedagogue's life activities on the ground of the theories of personality's holistic aspect and identity's theoretical concepts with particular focus on the theoretical researches on pedagogue's professional identity can draw conclusions and offer a theoretical research model of pedagogue's identity and factors influencing development thereof (see Picture 1).

\section{Factors Influencing Development of Pedagogue's Identity}

The most significant factors influencing the development of the pedagogue's professional identity are the acceptation of choice, participation and recognition (Maslo \& Fernàndez Gonzàles, 2015; Day, Stobart, Sammons, Kington \& Gu, 2007; Riegel, 2004; Hasbrauer, 2001; Deming, 1951) along with trust and safety which is interpreted in context of life quality by Tisenhofs and Meņšikovs (Tisenkopfs, 2006; Meņšikovs, 2006) and ought-being which includes moral, aesthetic ideals, philosophy and religion (Lasmane, 2007, 2001a, 2011b; Rubenis, 1997; Milts, 2005).

The ideals of ought-being can be individual or social. The aspect of values outlines the dimension of ought-being and indicates the divide between the achieved and the ideal state (Tisenkopfs, 2006: 15). Approaching the ideal depends on capacity i.e. the unity of characteristics, skills and activities that allows to develop an appropriateself-realisation model [..] The capacity integrates all available "inner" and "outer" resources of human - education, properties, finances, social connections etc. The capacity is an active life mechanism, which connects knowledge and practice, recourses and activities. The capacity is influenced by education, social background, upbringing; it changes during the lifetime and is affected by human's experience (Tisenkopfs, 2006: 19).

The individual choice in pedagogue's life activities develops the feeling of self-regulation and capacity to reflect on one's work, which is the most effective way of gaining competences. However, social recognition (from the employer) and individual recognition (job satisfaction, feeling of doing the right thing etc.) encourage to start new initiatives and the individual desire to improve one's work and life quality by acting in different social areas, which Bourdieu defines 
within the concept of habitus, and accrue economic, social, cultural, symbolic and political capital (Bourdieu, 2004: 151-164).

The participation is connected to trust which is an emotional attitude (Roukonen, 2013), a psychological state which is open to possible vulnerability (Vanneste, Puranam \& Kretschmer, 2014; Coleman, 1990; Rousseau et.al., 1998; Bhattachary et.al., 1998; Mayer et.al., 1995).

The main aspect of safety is human safety, which according to Thomas is an existential state when the basic needs are satisfied and the participation in community life can happen. Ozolina outlines the aspect of objective conditional and subjective feeling, interaction between outer factors and internal governmental structure (Ozolina, 2012). In addition, Ijabs connects the safety to risk awareness and outlines that the future awareness influences presence. Thus, the human's identity becomes reflexive and individuals have to agree on choices concerning one's lifestyle (Ijjabs, 2012, 87).

\section{Discussion}

*Pedagogue's identity is connected to multi-dimension interpretation and holistic approach to pedagogue's personality considering the component of professional identity.

*Professional identity is a continuous interpretation and reinterpretation process of experience and it never stops which can be understood as lifelong learning. It is dynamic and in context of professional development searcher for answers who am I at the moment? and what I want to be?

*Professional identity includes both individual and contextual understanding and it is not single. It is expected from teachers that they behave and think professionally in addition to knowledge and attitudes. Teachers differ according to the way they realise the professional features; there is not a common teaching technique in school and each teacher can develop his/her own teaching culture.

*The professional identity is formed by part-identities (Illeris, 2014) or sub-identities, which are connected to different contexts and relationships. Some of these identities can be defined as the base of teacher's professional identity, while others are more peripheral. It is important for pedagogue that the subidentities are not in contrast. Experienced teachers feel the contrast when there are changes in educational system or work environment. The more important is the sub-identity, the more difficult is the change.

*According to Coldron and Smith (Coldron \& Smith, 1999) pedagogues should be active in their professional development. It includes individual learning from peers and cooperation. Professional identity is not something the 
teachers have; it is something they use to make sense of themselves as teachers (Beijaard, Meijer \& Verloop, 2004: 123).

\section{Conclusions}

1. The structure of pedagogue's personality consists of the dispositional traits of personality i.e. emotions, talent, behaviour and opinion, along with the adaptation characteristics i.e. interests, motivation, values, attitudes and character within micro (individual), mezzo (studying, working, family, daily, community) and macro (education, ethical, geographical, political, cultural environment).

2. The categories of the pedagogue's identity are emotions, behaviour, talent, character, interests, motivation, values and attitudes, which develop in the micro context, family, pedagogue's, daily, student's and religious identity in mezzo context and professional, national, local, political and cultural identity in macro context within the socialisation process influenced by the factors as choice, participation, recognition, trust, safety and ought-being.

3. The research model of pedagogue's identity is variable. It reflects the dynamic relationships among all the components of the model. The model is a tool to be used for pedagogues' identity researches in any definite cultural environment, considering that the timeframe is defined and the defined influential factors of personality development are taken into account.

\section{References}

Abrams, L. (2010). Oral History Theory. London \& New Yourk: Routledge.

Akadēmiskā personāla biogrāfiskais rādītājs. (2007). Ed. Arturs Medveckis. Liepāja: LiePA. Alheit, P. (1992). The Biographical Approach to Adult Education. In Wilhelm Mader (sd.): Adult Education in the Federal Republic of Germany: scholarly approaches and professional practice. Vancouver: University of British Columbia.

Alheit, P. (1999). Biographical Learning: within the new lifelong learning discourse. In Knud Illeris (ed.): Contemporary Theories of Learning. London: Routledge.

Balantine, H. J. \& Roberts, A. K. (2009). Our Social World: Introduction to Sociology. 2nd edition, Los Angeles, London, New Delhi, Singapore, Washington DC: SAGE.

Baldvin, J. (2009). George Herbert Mead. Sage.

Bela-Krūmiņa, B., Krūmiņš, J., Kursīte-Pakule, J., Priedīte-Kleinhofa, A., Putniņa, A., \& Šķiņksis, P. (2005). Cilvēki un vietas. In: Zobena, A. Latvija. Pārskats par tautas attīstību 2004/2005: Rīcībspēja reǵionos. Rīga: LU Sociālo un politisko pētījumu institūts, 21.-45. lpp.

Berger, P. L., \& Luckmann, T. (1966). The Social Construction of Reality. A Treatise on sociology of Knowledge. Garden City, NY: Anchor Books.

Bhattacharya, R., Devinney, T. M., \& Pillutla. M. M. (1998). A formal model of trust based on outcomes. Academy of Management Review 23 (3), pp. 459-472. 
Bisley, N. (2007). Rethinking globalization. Basingstoke: Palgrave Macmillan.

Bruning, S. (2002). Relationship building as a retention strategy: Linking relationship attitudes and satisfaction evaluation to behavioural outcomes. Public Relations Review, 28 (1), pp. 39-48.

Burdjē, P. (2004). Praktiskā jēga. Rīga: Omnia mea.

Callanan, G. A. (2003). What price career success? Career Development International, Vol. 8, No. 3, pp. 126-133.

Celms, T. (1933). Tagadnes problēmas. Rīga: Valters un Rapa.

Charon, J. M. (2004). Symbolic Interactionism: An Introduction, and Interpretation, an Integration. Upper Saddle River, New Jersey: Pearson Prentice Hall.

Coldron, J. \& Smith, R. (1999). Active location in teachers' construction of their professional identities. Journal of Curriculum Studies, 31 (6), pp. 711-726.

Coleman, J. (1990). Foundations of Social Theory. Harvard University Press: Cambridge, MA.

Cross, P. K. (1981). Adults as Learners: Increasing participation and facilitating learning. San Francisco: Jossey-Bass.

Day, C., Stobart, G., Sammons, P., Kington, A., \& Gu, Q. (2007). Teachers matter: Connecting work, lives and effectiveness. New York: Open University Press.

Dāle, P. (1962). Gara problēmas. Čikāga.

Definitions of Values. Ethics Compliance Initiative. (http://www.ethics.org/ resource/definitions-values)

Deming, E. (1951). Elementary Principles of the Statistical Control of Quality. Tokyo: Nippon Kagaku Gijutsu Renmei.

Beijaard, D., Meijer, P. C., \& Verloop, N. (2004). Reconsidering research on teachers' professional identity. Teaching and Teacher Education, 20, pp. 107-128.

Druviete, I. (2010). Latviešu valoda kā valsts valoda: simbols, sazinas lìdzeklis vai valstiskuma pamats? Latvija un latviskais. Nācija un valsts idejās, tēlos un simbolos. Ed. Ausma Cimdina, Deniss Hanovs. Rīga: Zinātne.

Ekman, P. (1992). An argument for basic emotions. Cognition \& Emotion, 6, pp. 169-200.

Eriksen, T. H. (2010). Saknes un pēdas. Identitāte main̄̄gā laikāa. Rīga: Zvaigzne ABC.

Ēriksens, T. H. (2010). Mazas vietas - lieli jautājumi. Ievads sociālantropologìijā. Rīga: LU Akadēmiskais apgāds.

Fox, E. (2008). Emotion Science: An Integration of Cognitivand Neuroscientific Approaches. Palgrave MacMillan.

Gidenss, E. (1999). Sabiedrības veidošanās. Rīga: Izdevniecība “AGB”.

Gīrcs, K. (1998). Kultūru interpretācija. Rīga: Izdevniecība “AGB”.

Gudjons, H. (1998). Pedagogijas pamatatzinas. Rīga: Zvaigzne ABC.

Hasbrauer, P. (2001). Partizipative Strukturen und eine Kultur der partizipation in der Heimerzienbung. Forum Erziehungshilfen, Jg 7, S. 9-14.

Hoks, D. (2007). Kultūras nozīme valsts attīstības plānošanā. Cēsis: Culturelab.

Ideju vārdnīca. (1999). No angḷu valodas tulkojuši Z. Ikere, J. Markots, N. Pukjans, M. Treilona. Rīga: Zvaigzne ABC.

İjabs, I. Risks un drošumspēja: sociālā teorija un Latvijas perspektīva. Cilvēkdrošība Latvijā un pasaulē: no idejas līdz praksei. Apgāds "Zinātne". (http://www.gabrielekoehler.net/ Data/Sites/1/userfiles/cilvekdrosiba_labots-2.pdf.)

Illeris, K. (2014). Transformative Learning and Identity. First published 2014 by Routledge 2 Park Square, Milton Park, Abington, Oxon OX14 4RN. 
Izard, C. (2009). Emotion Theory and Research: Highlights, Unanswered Questions, and Emerging Issues. Annu. Rev. Psichol., 2009, 60, pp. 1-25.

Jenkins, R. (2008). Social Identity. 3rd edition. London, New York: Routledge.

Karpova, Ā. (2005). Personības psiholoǵiskie model̦i izcilo pedagoǵiskās domas kopēju dzīvesdarbības atspoguḷojumos. Laikmets un personība. Sastādītāja un zinātniskā redaktore Aīda Krūze. Rīga: RaKa, 2005, 9.-40. 1pp.

Koroḷeva, I., Rungule, R., Sniķere, S., \& Aleksandrovs, A. (2009). Jauniešu identitāte un lìdzdalība. Latvijas jaunatnes portrets: integrācija sabiedrībā un marginalizācijas riski. Rīga: LU Akadēmiskais apgāds, 145.-189. lpp.

Lasmane, S. (2011). Nacionālās saesības apzināšanās un vēlmes. In: Nacionālās identitātes komunikācija Latvijas kultūras telpā. E-grāmata. Ed.: Jurğis Šḳilters un Skaidrite Lasmane. Rīga: LU SPPI (http://academia/lnb.lb/xmlui/handle/123456789/4).

Lasmane, S. (2011). Cita triāde: intelekts, ētika, patība. (2011). In:Laika atšalkas: žurnālistika, kino, politika. E-grāmata. Ed. Olga Proskurova. Rīga: LU SPPI, (http://academia/lnb.lb/xmlui/handle/123456789/6).

Lasmane, S. (2007). Morālās uzraudzības un vērtējuma ne/efektivitāte. In: Lasmane, S. (red.). Politiskā komunikācija, ètika un kultūra LR 9. Saeimas vēlēšanās. Rīga: LU Akadēmiskais apgāds, 280.-295. lpp.

Lāce, I. (2011). Latvijas pedagogu karjeru ietekmējošie faktori. Sabiedriba, integrācija, izglītîba. I daļa. Rēzekne: Rēzeknes augstskola, 139.-148. lpp.

Lieǵeniece, D. (1992). Bērns - pasaulē, pasaule - bērnā. Rīga: Zvaigzne.

Lieg̉eniece, D. (2002). Ievads andragoǵijā jeb Mācīšanās "būt”" pieaugušo vecumā. Rīga: RaKa.

Lieǵeniece, D. (1999). Kopveseluma pieeja audzināšanā. Rīga: RaKa.

Lieǵeniece, D. (1996). Kopveseluma pieeja 5-7 gadus veca bērna audzināšanā. Liepāja: LPA.

Lieǵeniece, D. (2013). Kopveseluma pieeja 5-12 gadu vecu bērnu uzvedības izpratnei sociālajā vidē. Holistic Approach to Understanding Behaviour of 5-12 Year Olds in a Social Environment. Society, integration, edukation. Proceedings of the International Scientifical Conference. Rēzekne: Rezekne Higher Education Institution Faculty of Education and Design PersonalY Socialization Reserch Institute in Collaboration With University of Udine, Italy, 37.-47. lpp.

Liepājas Pedagoǵijas akadēmijas darbinieku dzīvesstāsti. 1. edition. (2004). Ed. A. Medveckis. Liepāja: LiePA.

Liepājas Pedagogijas akadēmijas darbinieku dzīvesstāsti. 2. edition. (2006). Ed. A. Medveckis. Liepāja: LiePA.

Liepājas Pedagoğijas akadēmijas darbinieku dzīvesstāsti. 3. edition. (2009). Ed. A. Medveckis. Liepāja: LiePA.

Macionis, J. J., \& Plummer, K. (1998). Sociology: a Global Introduction. Harlow: Prentice Hall.

MacKeracher, D. et al. (2004). Making sense of adult learning (2nd ed.). Toronto, ON: University of Toronto.

Maddi, S. R. (1996). Personality theories: A comparative analysis (6th ed.). Pacific Grove, CA: Brooks/Cole.

Maslo, I., \& Fernández González, M. (2015). Supporting the engagement and reintegration of 18-24 year old early school-leavers in lifelong learning: evidences for targeted compensatory and preventive strategy in education. Report. University of Latvia, Faculty of Education, Psychology and Art, Scientific Institute of Pedagogy. 
Maslow, A. (1954). Motivation and personality. New York: Free Press.

Mayer, R C., Davis, J. H., \& Schoorman, F. D. (1995). An integrative model of organizational trust. The Academy of Management Review 20 (3), pp. 709-734.

McAdams, D. P., \& Pals, J. L. (2007). The role of theory in personality research. In: Robins Richard (Ed.). Handbook of research methods in personality psychology New York: Guilford Publication, Inc, pp. 3-25.

Medveckis, A. (2013). Biographical Approash in Pedagogical Research: from Life Story to Monograph. Society, integration, education. Proceedings of the International Scientifical Conference. Rēzekne: Rezekne Higher Education Institution Faculty of Education and Design PersonalY Socialization Research Institute in Collaboration With University of Udine, Italy, pp. 423-438.

Medveckis, A. (2014). Biogrāfiskās izpētes avoti un literatūra. Aktuālas problēmas literatūras zinātnē: 19. Zin. red. Edgars Lāms. Liepāja: LiePA. 2014.

Medveckis, A. (2015). Model of teachers identity factors in the biographical research. Internacional Journal of Multidisciplinary Thought. CD-ROM. ISSN: 2156-6992: 08(01): 85-98.

Medveckis, A. (2012). Kārlis Rūdolfs Kreicbergs un vina laiks. Liepāja: Liepājas Universitātes Sociologisko pētījumu centrs.

Medveckis, A. (2012). Kultūrvides pārvērtību liecības biogrāfiskās izpētes avotos (Latvian cultural environment transformation testmonies in biographical reserch sources) Novadnieciskās identitātes meklējumi Kurzemē. Liepāja: Liepājas Universitāte, 53.69. lpp.

Medveckis, A. (2013). Biogrāfiskā pieeja pedagogískos pētījumos: no dzīvesstāsta līdz monogrāfijai. Sabiedrība, integrācija, izglītība. Rēzeknes Augstskola. Izglīīîbas un dizaina fakultāte, Personības socializācijas pētījumu institūts sadarbībā ar Udines universitāti, Itālija, 423.-437. lpp.

Medveckis, A. (2013). Latvian cultural environment transformation testimonies in Liepaja University seniors' biographical research sources. Humanities and Social Sciences Review. CD-ROM. ISSN:2165-6258: 2(4): 117-129.

Medveckis, A. (2013). Lūcija Prindule dz̄ivē un zinātnē. (Biogrāfiska apcere iesniegta publicēšanai Latvijas Universitātes sērijveida izdevumam Laikmets un personība.)

Meņšikovs, V. (2006). Dzīves kvalitāte Daugavpilī. Rīga: Zinātne, 153.-178. lpp.

Mihailova, S. (2015). Emocijas. Psihologija 1. pamatjautājumi - teorijas un pètījumi. Rīga: Zvaigzne ABC, 171.-216. 1pp.

Mikelsone, I., Odina, I., \& Grigule, L. (2014). Conceptualizing the understanding of professional identity in teacher's career. European Scientific Journal November 2014 /SPECIAL/ edition vol. 1, pp. 238-249.

Milts, A. (2005). Atmina un sirdsapziņa. Kentaurs XXI. Nr. 38, 126.-133. lpp.

Moore, M., \& Hofman, J. E. (1988). Professional identity in institutions of higher learning in Israel. Higher Education, 17 (1), 69.-79. 1pp.

Nixon, J. (1996). Professional identity and the restructuring of higher education. Studies in Higher Education, 21 (1), pp. 5-16.

Ozoliņa, Ž. (2012). Cilvēkdrošǐba vai iespējams visaptverošs definējums? Cilvēkdrošǐba Latvijā un pasaulē: no idejas lìdz praksei. Rīga: Zinātne. (http://www.gabrielekoehler.net/Data/Sites/1/userfiles/cilvekdrosiba_labots-2.pdf.)

Paechter, C., \& Head, J. (1996). Gender, identity, status and the body: Life in a marginal subject. Gender and Education, 8 (1), pp. 21-29. 
Parsons, R.M. (2011). Fundamentals of the Helping Process. 2nd Edition. Waveland Press, Inc.(https://books.google.lv/books?id=kYsbAAAAQBAJ\&pg=PA7\&dq=helping+proce ss+values\&hl=lv\&sa=X\&ei=LJ2bVZqiD4WssAHGk4_IBQ\&ved=0CB4Q6AEwAA\#v $=$ onepage $\& \mathrm{q}=$ helping $\% 20$ process $\% 20$ values $\& \mathrm{f}=$ false)

Pedagogijas terminu skaidrojošā vārdnīca. (2000). Sast. autoru kolektīvs Valentīnas Skujiñas vad. Rīga: Zvaigzne ABC.

Phelan, A. M. (2000). A knot to unfurl (A book reviewof 'Shaping a professional identity: Stories of education practice' by M. F. Connelly \& D. J. Clandinin, 1999, London, ON: Althouse Press). Alberta Journal of Educational Research, 46, 288-290.

Plutchik, R. (2002). Emotions and Life: Perspectives from Psichology, Biology, and Evolution. Washington, DC: American Psichological Assotiation.

Riegel, C. (2004). Im Kampf um Zugehörigkeit und Anerkennung. Frankfurt am Main. London.

Ruokonen, F. (2013). Trust, Trustworthiness, and Responsibility. In: TRUST Analytic and Applied Perspectives. Amsterdam - New York, Edited by Pekka Mäkelä and Cynthia Townley, p. 1-11.

Rousseau, D. M., Sitkin, S. B., Burt, R. S., \& Camerer, C. (1998). Not so different after all: a cross-discipline view of trust. Academy of Management Review 23 (3), pp. 393-404.

Rubenis, A. (1997). Ėtika XX gadsimtā. Rīga: Zvaigzne ABC.

Samuseviča, A. (2013). Radošā pedagog̣ijas zinātniece Daina Lieǵeniece. Sast. un zinātniskā redaktore LU profesore Dr. paed. Aīda Krūze. Laikmets un personība 14. Latvijas Universitāte. Pedagoǵijas, psiholog̣ijas un mākslas fakultāte. Pedagoğijas muzejs. Rīga: RaKa.

Schwarz, N., \& Bohner, G. (2001). The Construction of Attitudes. Manuscript of a chapter inA. Tesser \& N. Schwarz (Eds.) Intrapersonal Processes (Blackwell Handbook of Social Psychology) Oxford, UK: Blackwell, pp. 436-457.

Schiefele, U., \& Krapp, A. (1996). Topic interest and free recall of expository text. Learning and Individual Differences, 8, pp. 141-160.

Schiefele, U., Krapp, A., \& Winteler, A. (1992). Interest as a predictor of academic achievement: A meta-analysis of research. In K. A. Renninger, S. Hidi \& A. Krapp (Eds.), The role of interest in learning and development Hillsdale, NJ: Erlbaum pp. 183212.

Stepčenko, A. (2014). Nacionālās, reǵionālās identitātes un telpas strukturācijas interference. Ad locum: vieta, identitāte un rīcībspēja. Rīga: LUAkadēmiskais apgāds. 41.-65. lpp.

Strika, E. (2009). Tiesu psihiatriskajā vai kompleksajā tiesu psihologiskajā un psihiatriskajā ekspertīzē nonākušo likumpārkāpēju personības raksturojums. Promocijas darba kopsavilkums. Rīga: Latvijas Universitātes Pedagoǵijas un psihologijas fakultātes Psihologijas nodaļa.

Students, J. A. (1928). Ievadījums psihologijāa. Programma konspekts pašmācībai. Rīga.

Students, J. A. (1930). Psiholoğija ǵimnāzijām. Rīga.

Students, J. A. (1935). Bērnu, pusaudžu un jauniešu psihologiija. Rīga.

Sugrue, C. (1997). Student teachers' lay theories and teaching identities: Their implications for professional development. European Journal of Teacher Education, 20 (3), pp. 213225.

Špona, A. (2006). Audzināšanas process teorijā un praksē. Rīga: RaKa.

Tajfel, H. (1978). The achievement of group differentiation. Differentiation between social groups. Studies in the social psychology of intergroup relations., London: Academic Press, pp. 77-98. 
Proceedings of the International Scientific Conference. Volume IV, May $27^{\text {th }}-28^{\text {th }}$, 2016. 80-96

Thompson, P. (2000). The voice of the past. Oral history. Oxford: Oxford University Press.

Tīsenkopfs, T. (2006). Ko nozīmē laba dzīve mūsdienu Latvijā? Rīga: Zinātne, 13.-37. lpp.

Vanneste, B. S., Puranam, P., \& Kretschmer, T. (2014). Trust Over time in Exchage Relationships: Meta-Analysis and Theory. Strategic Management Journal. Strat. Mgmt. J., 35, pp. 1891-1902.

Vikmane, B. (2009). Socializācija ğimenē. Liepāja: LiePA.

Volāne, E., \& Špons, A. (2010). Dzīvesdarbības prasmju apguve mājturības un tehnolog̣iju stundās skolā. Teorija praksei mūsdienu sabiedrības izglìtībā. V Starptautiskā konference. Rīga: RPIVA, 382.-389. lpp.

Volkovs, V. (2015). Sociālās identitātes pētījumi Liepājas Universitātes zinātniskajās konferencēs „Sabiedrība un kultūra”. Sabiedrība un kultūra. Rakstu krājums, XVII. Liepāja: LiePA. 11.-21. lpp.

Volkovs, V. (2011). Sociologijas teorijas. Liepāja: LiePA.

Zobena, A., Grīviņš, M., \& N̦ikišins, J. (2014). Vieta, identitāte un rīcībspēja. Ad locum: vieta, identitāte un rīcībspēja. LUAkadēmiskais apgāds, 7. lpp. 